\title{
Intensify Business Performances of Multinationals: An Introduction to Five Strategic Elements within Performance Management
}

\author{
Daniel Feyerlein ${ }^{1}$ \\ ${ }^{1}$ Consultant, Heideck, Germany \\ Correspondence: Daniel Feyerlein, Heideck, Germany. E-mail: daniel.feyerlein@googlemail.com
}

Received: December 4, 2016

Accepted: February 25, 2017 Online Published: April 27, 2017

doi:10.5539/ijbm.v12n5p17

URL: https://doi.org/10.5539/ijbm.v12n5p17

\begin{abstract}
The unknown future of global change, the increasing influence of growing and altered market conditions - these critical issues require companies around the globe that operate internationally to progressively adapt and optimize their strategies. In particular, regarding future competition conditions, strengthening competitiveness is gaining more importance. Companies are being challenged to define their business models and strategies in accordance with global requirements in order to compete successfully.

Particularly in times of inconsistency, suggestions for performance improvement can provide valuable impulses. This article highlights current aspects within international business and considers future market conditions with a focus on strategic management and raising competitiveness.

Performance management, the core element of business models, suggests five strategic elements that show promising potential for improving the performance of multinationals: beneficial proposals, commercial excellence, leadership aspiration, gaining competitiveness and ecological sustainability. With a focus on strategizing, performance management aims at generating continuous improvement of the organization's competitive situation internationally while factoring in global change. This article focuses on manufacturing companies that pursue long term growth targets in international business and that has to deal with permanently growing competition at an international level.
\end{abstract}

Keywords: business model, competitiveness, performance management, strategy, multinationals

\section{Globalization, Competition and Prospects in the Information Age}

Since the initiation of globalization in the 1980s, the initial position of internationally acting companies has changed significantly. From the start, globalization was linked to false expectations: despite new technologies, costs increased; the information age led to a drastic cutback in proximity to customers; financial means are limited; fossil fuels and other resources continue to become costlier and will gradually be exhausted. It is predicted that the world population will continue to grow over the following decades, the economy will carry on shifting to Asia and cash flows will expand. Increasing consumer demands, which are linked to middle-class growth, is being confronted by the limited availability of energy and resources. As such, there is a radical distinction between future and present markets: future markets will be influenced by additional societal factors, which will lead to new consumer behavior; this in turn will offer new opportunities to all market actors.

Consumer power has noticeably increased since we entered the information age. Consumer influence on company performance, product individualization and quality level will entail still further changes. Currently, customers have even better opportunities for comparing and evaluating products according to their individual needs. Furthermore, consumers exhibit less loyalty toward brands. In the information age, multinational manufacturing companies profit from globalization, market deregulation and technological advancements in such a way that they have outstanding opportunities for adapting their production to future conditions. However, one needs to bear in mind that competitors and other actors benefit from the same advantages.

Globalization influences the current economic and political debate more than any other factor. This term is rarely defined or unilaterally reduced to having certain positive or negative economic impacts (Clegg \& Grey, 1996). With respect to the World Trade Organization (WTO), technological and cultural developments are accompanied by the deregulation of capital and product markets, as well as by international trade liberalization. Levitt (1983) describes the deregulation of markets as a convergence of markets. This convergence makes it easier to realize 
business advantages and enables activities such as large-scale production in countries where the greatest economic benefits can be achieved. Thus, the cross-border activities of companies continue to grow systematically.

The future business environment will be very different from that of today and of the past. According to a forecast of the business environment for the coming decades by Curry (2011), the business landscape will be built on eight characteristics: an increasing population, a shift towards Asia, financial flows, energy availability, resource scarcity, water and food scarcity, technology, and the proper response in globalization.

The changing environment will make it more difficult for future business activities to generate turnovers as in previous years, since growth is limited. Constraints such as over-taxation and ecological exposure that affect regions of Asia and Latin America will contribute to reaching the same level of expense as in, for example, Europe. Consumption will not increase at the same speed, because the employer incomes are lower. Moreover, their markets are well populated by local brands, which are effective in their own way in terms of serving local needs and demands. Theories of economics argue that there are always opportunities, particularly for technological innovation. The biggest problem with new technologies is that they may arrive on the market too late to influence the markets of tomorrow. Thus, 'business as usual' can expect to be interrupted. For this reason, the risk of being unprepared for any kind of interruption to ongoing business activities is significant (Curry, 2011).

Ongoing globalization in principle affects large companies; however, a growing number of small- and medium-sized companies are also being affected. A growing number of micro-multinationals (Prahalad \& Hamel, 1994), which are integrated in international networks through strategic alliances and other forms of cooperative organization, are competent in terms of increasing their share in the world market through the realization of specialization and the advantages of flexibility for competing against large or nationally-oriented companies (Naisbitt, 1994). The international orientation of a company's policy regarding strategic decisions about its international business activities will therefore shift from expectation to standard and from strategic options to a basic qualification. This makes it clear that globalization not only accelerates the risks and opportunities of international activities, but also requires political and environmental responsibility, as well as the adaptation of the company's strategy (Holtbrügge, 2004).

Today, globalization has taken on new directions and presents diverse circumstances for multinational corporations. The governments of emerging countries tend to display a limited willingness to open industries to multinationals, finding it risky to do so. According to Bremmer (2014), they instead attempt to protect local interests. Furthermore, governments build exchange reserves to raise exports, redefine national security according to global topics (which become additional political issues) and create diverse business environments that provide advantages to local corporations. This 'rise of state capitalism' has shifted the characteristics of globalization in the current era and represents a break with the past. Governments therefore control markets through politically loyal, public-sector companies (Bremmer, 2014). As such, multinationals face local competition that is supported by governmental provisioning. Multinationals should consider the strategic effects of state capitalism and ask whether the industry sector is strategically important to the government of the target market and the domestic market. Globalization still offers a broad variety of opportunities to multinational corporations. Following Bremmer (2014), multinationals will find opportunities in this new era of globalization; however, permanent strategic adaptation remains mandatory.

\section{Multinationals amid International Markets Changes}

The changing market conditions and the restricted growth potential when compared to international markets show that it will be increasingly difficult to reach sales targets solely on a national level. Nonetheless, interesting economic regions in Asia and Latin America are changing alongside increasing taxation. Likewise, the cost level is increasing, similar to that in Europe. In contrast, consumption is not increasing at the same rate due to customers' income being relatively low. However, if economic theories are true, these markets also offer a multiplicity of opportunities for multinational companies to generate their total revenue, particularly in the technical industrial sector. New technologies exhibit the disadvantage that they generally enter the market late. On the one hand, this is due to customer acceptance and demand, as well as adaptation to local needs; on the other hand, it is the result of the high prices entailed by new technologies. Therefore, it is not surprising that companies rarely manage to adapt the current market situation to their future requirements. When critically examined, these aspects show that the existing market conditions are subject to both predictable and unpredictable disruptions, and that all expectations encounter limitations. Consequently, the risk for corporations that do not prepare sufficiently for changes in market conditions increases. 
In principle, marketers need to understand the holistic market environment. They therefore need to define market wants, needs and demands. Market needs are in general standard human requirements such as air, education, food and water. The shift from needs to wants happens when a specific product will create satisfaction and when a specific want is assisted by financial abilities. However, not many customers know what they really need. Kotler and Keller (2006) describe such a situation as the learning mode of customers. Companies employ this learning mode to shape customers' wants in the direction of their products and company strategy. Giving customers exactly what they want may, however, be the wrong approach. Rather, companies must develop their customers' behavior. Responding to customer needs by simply following a make-and-sell philosophy creates a shift to a specific and individual sense-and-respond philosophy (Kotler \& Keller, 2006). Based on this assumption, marketers have access to different conceptual possibilities for responding to customer needs, as well as influencing customers' behavior and needs.

Enis (1974) defines buying behavior as "a process, which through inputs and their use though process and actions leads to satisfaction of needs and wants". Buying behavior, according to Kumar (2010), "refers to the buying behavior of final consumers, both individuals and households, who buy goods and services for personal consumption". Blackwell, Miniard, and Engel (2005) define customers' behavior as a complex and dynamic issue, so that its definition is neither easy nor universal. That is why different researchers have defined the concept of customers buying behavior differently. Solomon (1995) defines buying behavior as a process that covers a product's choosing, purchasing, using and disposal. This process leads to the satisfaction of their wants and needs. Schiffman, Hansen, and Kanuk (2008) suggests that the decision-making process employs available resources. Customer behavior has in the past been and remains a significant topic of research.

A clear understanding of customers' buying behavior that includes their needs and wants is essential. However, it is difficult to determine the exact reasons for customers' buying decisions and preferences, which are sometimes guided by emotional influences. However, in principle, seeking to understand and respect customers helps to achieve long term business success. According to Dru (2002), companies can achieve success by adopting a clear vision that transmits an adequate sense of direction by using advertising, product innovation, or other marketing tools. Kotler and Keller (2012) suggest that the marketplace is not what it used to be. The current marketplace is influenced by societal forces that create new forms of consumer behavior, as well as new challenges, possibilities and opportunities. It is well known that today's technology is shifting society from an industrial age to an information age. The industrial age was linked to mass production and consumption. More accurate production levels characterize the information age, with better-targeted communications and pricing, primarily achieved through the use of digital networks. Globalization offers better and different types of transportation, production and communication. This creates a more extensive environment for companies in which to initiate foreign business activities, offering consumers the possibility to buy products and services from global markets. Furthermore, the deregulation of industries generates competition and opportunities for growth. In addition, the expectations of consumers have shifted toward better service, more customization and higher quality. They can access and compare product details and differences via the Internet and are consequently less loyal to brands as a result of intelligent shopping behavior. Companies nowadays focus on customizing their products to consumers' needs. This individualization is offered particularly by ordering via the Internet. Online companies interact through personalized messages, relationships and customer-oriented services. Due to customer and market changes, corporations operating at an international level face changing market requirements and growing competition, which requires an improvement in their operational efficiency and strategic management. In order to compete successfully, adaptation to customers' product needs should be considered, taking into account products' specific advantages.

\section{Competitiveness}

From the company's political point of view, globalization primarily entails opportunities and risks for companies. Companies who adapted their strategy at an early stage to global aspects record a surge of profits, stock prices and shareholder value. Companies who continue to think and act in national categories are threatened increasingly in their existence. Therefore, according to Prahalad and Hamel (1994) in their argumentation that no industry is free from impact, the implication is that companies need to shift from national to international activities.

In the information era, customers are now able to seek and evaluate products or services according to their needs. Offering customization combines customized marketing with customized production. In this way, customization-oriented companies do not need to collect customer information, but can respond with a customized product (Anderson \& Narus, 1995). However, the information era requires a rethinking of marketing and of attributes for meeting customer needs and wants. According to Rust, Moorman, and Bhalla (2010), 
corporations need to reorganize their strategies to compete successfully, shifting customization according to customer relations. Creating value propositions in times of increasing international competition has become more important for corporations that face pressure in terms of costs. According to Anderson, Narus, and van Rossum (2006), each value proposition should be measurable, sustainable and distinctive. Thus, customer-value propositions contribute significantly to performance and strategy. To summarize, not only are strategic advantages and strategic targets paired with the right market and customer segmentation, but the right handling of customers' needs and wants also substantiates competitive advantages with long term ambitions in today's information era.

Companies in the international business world seek to achieve competitive advantages compared to purely nationally-oriented companies. Foreign management focus is on minimizing costs that follow local adjustments when acting abroad (Macharzina \& Engelhard, 1987). The management of multinational corporations differentiates various characteristics and combinations thereof, and overall confronts two contrary requirements: (1) differentiation that is strongly market-oriented; (2) standardization that focuses on global integration and is therefore strongly product-oriented. Multinational corporations face the challenge of combining the advantages of both these requirements, which necessitates a transnational concept (Prahalad \& Doz, 1987). To adapt to the global environment with a focus on gaining competitiveness, the configuration of value activities is important.

\subsection{Competitive Advantages of Multinationals}

Multinational companies often realize economies of scope or economies of scale. Overall, a company has strengths and weaknesses that will lead to competitive advantages. These are separated into cost leadership, differentiation and a focus on cost or differentiation (Porter, 1985). In addition to making the correct choice in terms of generic strategy, companies will lose competitiveness if they do not consider a wide range of industry factors. Furthermore, the industry environment is always changing, making competition more difficult and advancing globalization. To generate a strategic decision, identifying and classifying all participants within an industry is fundamental. The business environment at the time of analysis is not static and is subject to dynamic changes in the future, thus giving rise to the need for a permanent strategic adaptation. Companies can therefore achieve success for their products within their market by choosing the correct strategy and pairing it with a permanent adaptation (Porter, 1985).

Multinational companies can achieve competitive advantages not only by optimizing their international activities, but also through a total consideration of all their global activities. In this way, companies are confronted with two opposing requirements. These are the simultaneous exploitation of the benefits of local adaptation following differentiation advantages and the exploitation of the benefits of global integration following unification, that is, standardization advantages (Welge \& Holtbrügge, 2006). With regard to international management, research suggests that these requirements do not represent extreme positions, but are independent dimensions.

In the context of an international study by Deloitte (2012), 550 CEOs were asked for their evaluation of production in the context of global change, as well as expected trends and their views on competitiveness in the future. The objective of this survey was to illustrate the complexity of the diverse parameters for production and product procurement, which require a reshaping of today's strategies for future conditions. The aspect of production thereby involves all steps of the value chain, beginning with research and development, production, logistics and marketing, to customer service and finally distribution and service. Understanding this chain is of major significance for companies for securing their competitiveness. This calls for insight into the strategic possibilities that manufacturing enterprises generally have. According to Porter (1985), it appears that organizational competitiveness levels are constantly influenced by four factors that illustrate their possible entrepreneurial freedom of action (Figure 1).

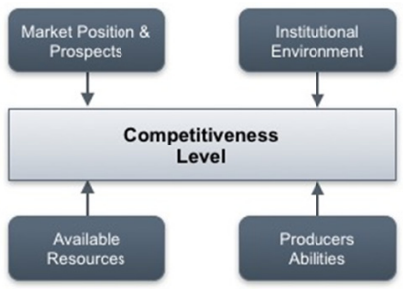

Figure 1. Factors influencing competitiveness according to Porter (1985)

Source: author's illustration. 
Available resources: resources that a company holds are, among others, its employees, financial opportunities and energy and material resources.

Market position and prospects: positioning within the market as well market conditions can be differentiated by demographic aspects, as well as by national and international activities such as micro- or macroeconomics.

Producers' abilities: a manufacturer's abilities are focused on innovation opportunities, using and benefitting from technologies, optimization of processes and the creation of infrastructure.

Institutional environment: research and development, regulation of manufacturing, infrastructural circumstances, labor force, finance and tax politics, education and science are positioned within the institutional environment.

When analyzing these four factors for any company and its business model, there appears to be a broad spectrum of possibilities for effecting improvement, as well as opportunities to differentiate from the positioning of competitors. The Deloitte (2012) study specifies the most important criteria for a modern and effective production within the industrial sector as experience, knowledge, creativity and assets and technologies.

If these four factors can be transferred from today's dominating markets to the competitiveness of future markets, it can be concluded that the BRIC States (Brazil, Russia, India and China) will become even more important and gain further competitiveness within international markets. Meanwhile, developed markets will lose importance and the competitiveness of companies in these markets will decrease. According to Hausmann and Hidalgo (2011), the effect of this has been an economic boom in nations in manufacturing and sourcing once they established production possibilities for international manufacturing companies. Therefore, internationally acting companies are permanently exposed to rapidly changing basic conditions with regard to competition, as well as within the entire production process at an international level, which renders continuous stabilization of production and competition advantages along the value chain indispensable.

\subsection{Markets and Requirements}

Today's market can be categorized into emerging markets and developed markets. Emerging markets distinguish themselves through the expectation of strong economic growth and an increase in the social middle class, along with their consumer demands. However, the demand-supply ratio and consumer expectations differ from market to market. Emerging markets excel by increasing purchasing power, which is currently targeted at products adapted to particular market conditions. This means that products require market-oriented price and product characteristics that satisfy the market's requirements.

The trend in developed markets presents itself differently; developed markets have encountered austerity policy on the part of governments and therefore, fewer governmental investments, whereby economic growth is restricted. Consumers' buying decisions are progressively influenced by whether products fulfill market-oriented criteria for improvement in efficiency, individualization and adaptation to customer requirements. Consumer behavior also changes; based on well-developed information sources end customers can compare their preferred products easily and choose the product with the highest benefit in relation to the price that they are willing to pay. In these markets, trends and prestige are rated higher, because customers wish to stand out from the crowd. Therefore, in developed markets, the adaptation and reputation of products with regard to the requirements of the market are essential for successfully sustaining their position.

Despite demand and consumerism in emerging markets differing greatly from those in developed markets, the expectations to adapt to the particular market conditions and to the characteristics of each product are similar. A vital criterion for success in this regard is generating and supplying effectiveness of multinationals' business model, because it can be expected that consumerism in both market categories will also change. Consequently, the competition laws that companies will face in the future can be described as concerning the following: the right price-performance mix, new deciders that will have to be influenced, adaptation of product strategy to increasing cost pressures, positioning in the market and differentiation in light of competition. These changes will not only be encountered by internationally acting corporations, but also by solely nationally acting companies.

\section{Intensify Business Performances with Strategic Elements}

Globalization, customer behavior, market changes, competition and new international requirements are all challenges multinational companies currently deal with, and which will continue into the future. In order to adapt to these requirements, an individualized product and company strategy is necessary that will offer a success-oriented value proposition for the end customer. Furthermore, adaptation to future consumers and an overarching increase in company performance along the value chain should be considered. 
It is not easy to combine foreseeable changes in market conditions with an increase in efficiency and corresponding strategies. Well-positioned companies present their 'value promise' to the consumer within a strategically developed business model that incorporates aspects that capture value, create value and deliver value. Unfortunately, there is no standard concept for an optimized business model that guarantees success. However, it is possible to generate a holistic business model in the context of performance management by analyzing strategic elements and combining them as part of an appropriate strategy. The adaptation of these elements demonstrates additional prospects for companies with growth targets in times of global change and increasing competition that can help them to generate peak performance (Figure 2).

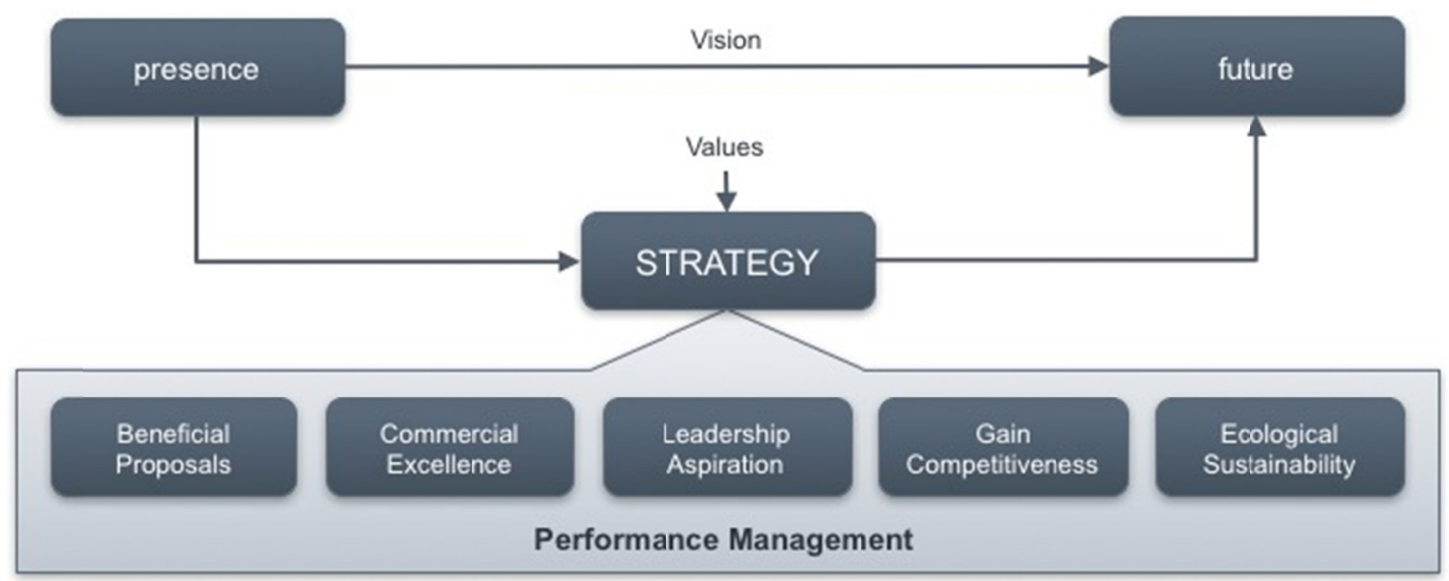

Figure 2. Five strategic elements within performance management

Source: author's illustration.

\subsection{Beneficial Proposals}

In the information age, markets are moving toward distinctly individualized demands, which entail the necessity for individualized products. Correspondingly, developing companies are interested in further differentiating and individualizing their offered products to specific consumer needs. This incorporates the development of demand-driven product portfolios, which result from earlier market research and their adaptation to market conditions. For manufacturing companies, it appears that combining superior technology while at the same time maintaining established quality standards serves as a formula for success. A classification, for example, "Made in Germany", is and should remain a qualitative measurement attribute. Above all, there is the provision of added value for the customer, which can ultimately convince them to buy a preferred product. This added value can present itself via a range of different characteristics and can be blended with positive aspects that are viewed as crucial by all companies, and also reflect customer and market demands. Added value will differ from one market to another, however; particularly successful will be products that incorporate added value via measurable criteria, because when compared to other products, they will present verifiable arguments accompanying their purchase.

Exemplified adaptation: the range of offered goods will be extended for individualized consumer demands in the premium sector. Instead of a standardized solution for the entire premium sector, a perfect and individualized solution will be offered based on a prior counseling interview, by which the company can distinguish itself from its competition. A fundamental element of all activities in this context is the creation of added value, so that customers are willing to pay an additional charge.

Brief notes:

- Individualization to customers and market demands matters

- Obtain customer attention via specific proposals

- $\quad$ Add value to products or services that customers specifically seek out

\subsection{Commercial Excellence}

Having the right product on the market at the right time without establishing in parallel an equivalent sales model can be critical. The expansion and advancement of sales models are essential components of growth. 
Particularly for multinational companies, it is imperative to consider natural aspects that, in turn, reflect customer demands. For example, the classification of products' origins with a seal of quality generally has the connotation of being expensive, and offers the certainty that the technology and quality thereof are above average. Customers are willing to invest more in new technologies and the highest quality standards; however, price will nonetheless in most cases be the deciding buying factor for whether the product is bought (Feyerlein \& Habib, 2014). This variance cannot be discounted; therefore, companies should attempt to combine the values of a manufacturer with the established standards of technology, quality and available market-specific purchasing power in order to generate an added value-price blend. In this way, product quality cannot be degraded, but must still be affordable to customers. An appropriate adaptation can always be optimized along the value chain. Also, payment models that are adapted to market conditions can result in success, because payment behavior can change likewise. The proper payment alternative can certainly contribute to increasing competitiveness, generating the desired sales and possibly dominating the market, particularly when the company actively reacts to their paying customers' desires and habits, in addition to offering alternatives. In order to generate commercial peak performance, it is essential to strive for the undeviating market presence of both the company and the product. At best, this should ensure that customers and decision makers have no other choice but to include the company and the appropriate product in their evaluation of product alternatives. Comparisons with the competition is also a good approach, as competition generally stimulates business and simplifies for the customer the process of defining relevant evaluation parameters. It also simplifies the process for the manufacturer, enabling it to compete and differentiate itself from others.

Exemplified adaptation: the company positions itself as an individual provider of solutions in its favored markets. By means of newly created strategic alliances and a complementary range of offered goods, the new sales model is tendered and added value is generated.

Brief notes:

- $\quad$ Adapt to customers or markets' payment behaviors and preferences

- Combine products or services with the added-value of using commercial tools

- Implement the right blend of quality, technology and price

- Synchronize the brand and product/service characteristics with market demands

\subsection{Leadership Aspirations}

The pursuit of a dominant role in the short-term through to the mid-term should be the goal in developed markets. Achieving this will secure technological and qualitative enhancement in the value of products within growth markets, and influence competitiveness in the long run. For example, the product classification "Made in Germany" and its positively associated characteristics regarding the latest technologies, the highest quality standards and the credibility of German high-class workmanship only have an effect when they are dominant in their own market. When it comes to emerging markets, however, it is imperative to pursue an increased presence and acquire a dominant position in the medium through to the long-term. To do so, it is essential to establish maximized stability within the market via major sales, due to impending changes as a result of an increase in exposure and hazards from emerging markets within the context of global change. The adaptation of the range of offered goods should be managed differently in developed markets than in emerging markets. Conditions in developed markets are to be viewed as a role model and should influence the preconditions of anticipated growth in emerging markets. Due to their market position and perceptions, dominant market players have many opportunities to positively influence the preconditions of future markets for their own products. An adaptation of market-oriented demand for product technology, quality and price, however, is indispensable to emerging markets.

Exemplified adaptation: the core market will be further stabilized to ensure an increase in the value of the offered products. Furthermore, enhanced participation in the market development of future markets is pursued based on market research and specific market development programs. These are designed proactively with the objective of becoming the market leader in the medium-term.

\section{Brief notes:}

- $\quad$ Obtain a dominant market position in developed markets

- Influence emerging markets positively

- $\quad$ Adapt to the market in focus 


\subsection{Gain Competitiveness}

Strengthening competitiveness is a continuous and ever-present topic in performance management and primarily favors the improvement of the value chain and the development of unique selling propositions. Changing or optimizing the supply chain as part of the entire value chain to new market conditions can strengthen the competitiveness within a short time, especially when economies of scope or economies of scale are considered. Reducing the complexity of products can also play a key role with regard to future markets. In this context, it is important to maintain established quality standards. However, this does not apply to their production site. Emerging markets offer the advantage of more cost-effective manufacturing due to more advantageous wage rates than in the country of origin. A relocation of production to cost-saving overseas sites can be problematic, however, where it concerns highly technological manufacturing methods linked to compliance with stabilized quality standards. Likewise, the transfer of knowledge should be viewed as critical. Alluring production conditions can as a result turn out to be cost traps. Emerging markets welcome multinational companies locating their production sites in the developing country while maintaining their standards for development, technology and quality. A comparison of all positive and negative aspects, including the consideration of ethical values still indicates that an improvement in the supply chain at an international business level can be a possibility. In view of future markets, such optimization can lead to enhancement of the price-performance ratio and therefore, to fortification of competitiveness.

Exemplified adaptation: current unique selling propositions (USP) will be shaped by innovative solutions into new USPs. As a solution provider, essential added value to the customer will be offered at the point where the company can distinguish itself from its competition. An extended range of offered goods thereby underlines flexibility and the company as a supplier of solutions. In this way, the added value as a whole can be communicated and publicized more efficiently.

\section{Brief notes:}

- Improve existing USPs and generate new USP's

- Enhance the company's value chain

- Maintain product and/or service attributes

- $\quad$ Optimize the price-performance ratio

\subsection{Ecological Sustainability}

The world today is not ecologically perfect. Climate change presents many risks and natural resources are constantly being exploited. The necessity for ecologically sustainable production processes and the appreciation of limited resources is of major importance for the future. Therefore, global markets demand optimization of existing resources and their integration into the value chain and business culture of all global businesses. According to forecasts, it is expected that there will be a $12.0 \%$ growth in sustainable products up to 2025 , compared to the predicted growth of global markets (Destatis, 2012). The aspect of sustainability presents a unique opportunity for multinationals to act as role models in order to generate further competitive advantages.

Exemplified adaptation: through intensified research and development into new materials and solutions, the added value of a product's origins will be expanded by additional criteria. A lead-in innovation will result in the necessity to create further USPs, which includes the need to respectfully handle resources.

Brief notes:

- $\quad$ Follow ecological prospects

- Implement them to new USP's

\section{Conclusion}

In summary, the strategic elements presented as part of performance management for establishing and maintaining strategies, products or services need to be adapted to markets; additionally, it is necessary to offer customers suitable added value. Concurrently, an effectively operating marketing model, ideally alongside attractive payment models, is of major importance. No less important is the pursuit of a dominant role in the developed market. If these conditions are met, the result will be an appreciation of the product and the company, which will consequently support a dominant role within emerging markets. The market conditions of developed markets are assumed by emerging markets, which are positively influenced by active commitment to the market events of multinational companies. The development of the characteristics necessary for a unique position, as well as improvement of the value chain to strengthen competitiveness requires on-going adaptation. 
Improvement of the supply chain is an opportunity within the international business environment that can lead to rapid success. The demand for sustainably manufactured products and responsible handling of resources increases and thereby presents further opportunities for creating additional competitive advantages.

When it comes to growth, companies need to look far ahead regarding investments. If they only invest when growth has become necessary, it is usually too late. Accordingly, companies should be more interested in bringing long-term growth potential to fruition through conscious planning and implementation, rather than pursuing an ad hoc strategy. Similarly, multinationals need to consider that business models and customer demands are subject to permanent change. Thus, a currently existing competitive advantage succumbs to market influences and consumers, and therefore cannot be maintained permanently.

Successful internationally-acting companies actively take part in market changes and continuously pursue improvements along the value chain. Hence, multinational companies that effect efforts oriented towards their future will not be able to function without continuous performance management and its implementation in their business model and strategy. They will require a well-adjusted strategy for their investments that on the one hand strengthens the current business model and supports competitiveness, and on the other also generates a future business model. They will need to evaluate new growth investments globally using longer time frames, while concurrently handling considerable strategic uncertainties that are typically entailed in investments. Additionally, the managing of an organization's range of offered goods has been criticized as well as recommended. However, with regard to investment, risk diversification considerably decreases risk, while at the same time increasing the range of offered products. Thus, companies with growth targets can present themselves more securely in terms of the changing international business conditions of the future.

The suggested strategic elements, i.e., beneficial proposals, commercial excellence, leadership aspiration, gain competitiveness and ecological sustainability within performance management enable unfettered utilization of promising potentials. Under the premise of the correct adaptation and implementation of a business model, performance management leads to the continuous improvement of the competition situation in national and international business environments. These five elements offer a simple starting point for preparing any corporation for future market changes. The adaptation and implementation of these elements, as well as the continuous development of competitiveness, is of major importance in the formulation of a suitable strategy. The transformation of the world markets offers organizations various opportunities and possibilities for market positioning; however, the risks must also be considered. All multinational companies are requested to thoroughly prepare for future business and customer behaviors as well as market requirements. The correct use of performance management can proactively manage critical issues in times of change and aid companies in strategically adapting and optimizing to achieve increased competitiveness in the long run.

This paper does not present a revolution so much as an evolution, since all the aspects and ideas mentioned have already been thoroughly researched and cited numerous times in diverse forms. Successful performance management, as a leading key element, will decide the success or failure of an organization. Success does not come about by accident, but is in fact the result of implementing a superior strategy. In order to successfully conquer the world markets, organizations require drive, good knowledge, courage, the correct motivation and a future-oriented strategy.

\section{References}

Anderson, J. C., \& Narus, J. A. (1995). Capturing the Value of Supplementary Services. Harvard Business Review, 73(1), 75-83.

Anderson, J. C., Narus, J. A., \& van Rossum, W. (2006). Customer Value Propositions in Business Markets. Harvard Business Review, 84(3), 90-99.

Blackwell, R. D., Miniard, P. W., \& Engel, J. F. (2005). Consumer Behavior. Mason: Thompson.

Bremmer, I. (2014). The New Rules of Globalization. Harvard Business Review, January-February, 103-107.

Clegg, S. R., \& Grey, J. T. (1996). Metaphors of Globalization: Postmodern Management and Organization Theory. Thousand-Oaks, London, New Delhi: SAGE

Curry, A. (2011). The Future Company - The World in 2020. Retrieved from http://thefuturescompany.com/free-thinking/the-world-in-2020/

Deloitte. (2012). Deloitte Touche Thomatsu Limited and The U.S. Council on Competitiveness (2012). 2013 Global Manufacturing Competitiveness Index. Retrieved from

Destatis. (2012). Test des OECD-Indikatorensets Green Growth in Deutschland. Retrieved from Wiesbaden: 
Dru, J. M. (2002). Beyond Disruption: Changing the Rules in the Marketplace. New York: John Wiley \& Sons.

Enis, B. M. (1974). Marketing Principles: The Management Process. Santa Monica, California: Goodyear Publishing Company.

Feyerlein, D., \& Habib, A. (2014). Affecting Customer Behavior through 'Made in Germany' within the Healthcare Sector. Asian Social Science, 10(15), 133-142.

Hausmann, R., \& Hidalgo, C. A. (2011). The Atlas of Economic Complexity: Mapping Paths to Prosperity. Retrieved from http://www.hks.harvard.edu/centers/cid/publications/featured-books/atlas

Holtbrügge, D. (2004). Multinationale Unternehmungen zwischen nationaler Verantwortung und globaler Effizienz. In H. A. V. Herrmann, K. I. (Ed.), Globalisierung und Ethik. (pp. 195-208). Berlin: Physica-Verlag HD.

Kotler, P., \& Keller, K. L. (2006). Marketing Management (12th ed.). Upper Saddle River, New Jersey: Pearson Prentice Hall.

Kotler, P., \& Keller, K. L. (2012). Marketing Management (14th ed.). Upper Saddle River, New Jersey: Pearson Prentice Hall.

Kumar, P. (2010). Marketing of Hospitality \& Tourism Services. Tata: McGraw-Hill Education.

Levitt, T. (1983). The Globalization of Markets. Harvard Business Review, 61(3), 92-102.

Macharzina, K., \& Engelhard, J. (1987). Internationales Management. Die Betriebswirtschaft (DBW), 47. Jg(3), 319-344.

Naisbitt, J. (1994). Global Paradox. Warum in einer Welt der Riesen die Kleinen überleben werden. Düsseldorf: ECON-Verlag.

Porter, M. E. (1985). Competitive Advantage: Creating and Sustaining Superior Performance. New York: Free Press.

Prahalad, C. K., \& Doz, Y. L. (1987). The multinational mission. Balancing local demands and global vision. New York: Free Press.

Prahalad, C. K., \& Hamel, G. (1994). Strategy as a Field of Study: Why Search for a New Paradigm? Strategic Management Journal, 15(Issue Supplement 2), 5-16.

Rust, R. T., Moorman, C., \& Bhalla, G. (2010). Rethinking Marketing. Harvard Business Review, January-February.

Schiffman, L., Hansen, H., \& Kanuk, L. (2008). Consumer Behaviour: A European Outlook. London: Pearson Education.

Solomon, M. (1995). Consumer Behaviour (3 ed.). New Jersey: Prentice Hall.

Welge, M. K., \& Holtbrügge, D. (2006). Internationales Management. Theorien, Funktionen, Fallstudien (4th ed.). Stuttgart: Schäffer-Poeschel.

\section{Copyrights}

Copyright for this article is retained by the author(s), with first publication rights granted to the journal.

This is an open-access article distributed under the terms and conditions of the Creative Commons Attribution license (http://creativecommons.org/licenses/by/4.0/). 